Бановша Гюлоглан гызы МАМЕДОВА, orcid.org/0000-0002-2578-1363 доктор философии по филологии, доиент кафедры инновачий в обучении Азербайджанского университета языков (Баку, Азербайджан) rus_rahimli@yahoo.com

\title{
ЯЗЫКОВАЯ ЛИЧНОСТЬ МАРГАРЕТ ДРЭББЛ: ЛИНГВИСТИЧЕСКАЯ РЕПРЕЗЕНТАЦИЯ ИНТРОВЕРСИИ
}

Целью этой статьи является исследование языковой личности Маргарет Дрэббл и анализ интровертной личности, нашедшей выражение в ее романе "The Millstone». B cmaтье используются методы, которые применяются в когнитивной лингвистике, в том числе в лингвосочионике - новом лингвистическом направлении и вербальной психодиагностике (в отношении дихотомий К. Г. Юнга). В ходе исследований становится известно, что Дреббл обладает интровертным психотипом, основанным как на мыслях автора о самом себе, так и на психологической идентичности созданных им образов типа альтер эго или на общих выводах, к которым пришли отдельные исследователи. Анализ языковой личности главного героя романа «TheMillstonе» показывает, что он отражает альтер эго автора. Назначение статьи - определить, является ли языковая личность самой М. Дрэббл, а также Розамунд Стадж, отражающей ее альтер-эго, экстравертом или интровертом в соответствии с дихотомией Юнга, и закрепить форму выражения этой особенности в художественном тексте. Известно, что Юнг в своем фундаментальном исследовании «Психологические типь» различал рациональный и иррациональный, эмоциональный (выводящий на первый план этический компонент) и мыслящчй (на первом плане - логика) типы, а также типы, усваивающие информацию с помощью сенсорньх органов чувств или с помощьью интуищии. На основании перечисленных типов сформировались дихотомии Юнга (рациональностьиррациональность; этика-логика; сенсорика-интуищия). В четвертой дихотомии Юнга в основном подчеркивается степень подготовки человека к коммуникации, его социальности и общительности, что охватывает интроверсию и экстраверсию, сравнительный анализ которых проводится автором в рамках этой статьи. По сравнению с экстравертами, людям-интровертам сложно разделять свое внимание на несколько частей, поэтому переключение внимания с занятия, которым они увлечены, на другой вид деятельности или с мысли, над которой они глубоко задумались, на другую идею представляет для них определенную трудность.

Ключевые слова: Маргарет Дрэббл, языковая личность, К. Г. Юнг, теория «психологических типов», интроверсия.

Бановща Гюлоглан гизи МАМЕДОВА, orcid.org/0000-0002-2578-1363 доктор філософії по філології, доиент кафедри інновачій в навчанні Азербайджанського університету мов (Баку, Азербайджан) rus_rahimli@yahoo.com

\section{МОВНА ОСОБИСТІСТЬ МАРГАРЕТ ДРЕББЛ: ЛІНГВІСТИЧНА РЕПРЕЗЕНТАЦІЯ ІНТРОВЕРСІї}

\begin{abstract}
Метою иієї статті є дослідження мовної особистості Марагарет Дреббл і аналіз інтровертної особистості, щзо знайшла вираження в ї̈ романі «The Millstone». У статті використовуються методи, які застосовуються в когнітивній лінгвістиці, в тому числі в лінгвосоціоніці - новому лінгвістичному напрямі і вербальній психодіагностиці (щодо дихотомій К. Г. Юнга). У прочесі досліджень стає відомо, щуо Дреббл володіє інтровертним психотипом, заснованим як на думках автора про самого себе, так і на психологічної ідентичності створених ним образів типу альтер его або на загальних висновках, яких дійшли окремі дослідники. Аналіз мовної особистості головного героя роману «The Millstone» показує, щуо він відображає альтер его автора. Мета статті - визначити, чи є мовна особистість самої М. Дреббл, а також Розамунд Стадж, щчо відбиває ї̈ альтер-его, екстравертом або інтровертом відповідно до дихотомії Юнга і закріпити форму вираження иієї особливості в художньому тексті. Відомо, шо Юнг у своєму фундаментальному дослідженні «Психологічні типи» розрізняв раціональний i ірраціональний, емоційний (виводить на перший план етичний компонент) $і$ мислячий (на першому плані - логіка) типи, а також типи, щуо засвоюють інформацію за допомогою сенсорних органів почуттів або за допомогою інтуїиї. На підставі перерахованих типів сформувалися дихотомї Юнга (раціональність-ірраціональність,
\end{abstract}


етика-логіка; сенсорика-інтуїція). У четвертій дихотомії Юнга в основному підкреслюється ступінь підготовки людини до комунікації, його сочіальності і товариськості, щуо охоплює інтроверсию й екстраверсію, порівняльний аналіз яких проводиться автором у рамках иієї статті. Порівняно з екстравертом, людям-інтровертам складно розділяти свою увагу на кілька частин, тому перемикання уваги з заняття, яким вони захоплені, на інший вид діяльності або з думки, над якою вони глибоко задумалися, на іншу ідею становить для них певні труднощі.

Ключові слова: Маргарет Дреббл, мовна особистість, К. Г. Юнг, теорія «психологічних типів», інтроверсія.

\author{
Banovsha Hiulohlan hyzy MAMEDOVA, \\ orcid.org/0000-0002-2578-1363 \\ Doctor of Philosophy in Philology, \\ Associate Professor at the Department of Innovation in Education \\ Azerbaijan University of Languages \\ (Baku,_Azerbaijan)rus_rahimli@yahoo.com
}

\title{
LINGUISTIC PERSONALITY OF MARGARET DRABBLE: LINGUISTIC REPRESENTATION OF INTROVERSION
}

\begin{abstract}
The purpose of the article is Margaret Drabble's exploration of language identity and definitely, the introvert identity expressed in her novel of "The Millstone" is analyzed. In this article the methods implied in cognitive linguistics, as well as in lingvosocionics which is a new linguistic direction and as well as verbal psychodiagnostics (with regard to Carl Gustav Jung's dichotomy) are used. As a result of explorations it becomes clear that either in the views the author told about herself, or referring to psychological identity of the images she created, or according to the common conclusion which was obtained by separate explorers Drabble possesses introvert psychotype. The study of language identity of the main hero of the novel of "The Millstone" gives ground to say that it embodies its author's alter-ego. The purpose of the article is to determine whether the linguistic personality of M. Drabble herself, as well as Rosamund Stage, reflects her alter ego, extrovert or introvert in accordance with Jung's dichotomy and to consolidate the form of expression of this feature in a literary text. It is known that Jung in his fundamental research "Psychological types" distinguished between rational and irrational, emotional (bringing to the fore the ethical component) and thinking (in the foreground - logic) types; as well as types assimilating information with the help of sensory organs or with the help of intuition. On the basis of the listed types, Jung's dichotomies were formed (rationality-irrationality; ethics-logic; sensorics-intuition). Jung's fourth dichotomy mainly emphasizes the degree of a person's preparation for communication, his sociality and sociability, which covers introversion and extraversion, the comparative analysis of which is carried out by the author within the framework of this article. Compared to extroverts, introverted people find it difficult to divide their attention into several parts, so it is difficult for them to switch attention from an activity in which they are passionate to another type of activity or from a thought that they have deeply thought about, to another idea.
\end{abstract}

Key words: Margaret Drabble, linguistic personality, C. G. Jung, theory of "psychological types", introversion.

Постановка проблемы. Благодаря многочисленным практическим и теоретическим исследованиям современная лингвистика доказала, что в создании теории языковой личности неизбежное участие приняли дихотомии К. Г. Юнга, а также основанная на них соционическая типология А. Аугустинавичюте. Лингвисты отмечают, что за каждым психологическим и соционическим типом скрываются не только эмоциональные и ментальные различия, но и языковые и речевые отличия личности. Эти различия связаны друг с другом причинно-следственной связью (Голев, 2009: 95-98). Другими словами, будучи интровертом или экстравертом, та или иная языковая личность выражает свою языковую идентичность в соответствующей форме. С другой стороны, только слушая можно определить принадлежность носителя языковой личности к конкретному психологическому типу.

Известно, что Юнг в своем фундаментальном исследовании «Психологические типы» различал рациональный и иррациональный, эмоциональ- ный (выводящий на первый план этический компонент) и мыслящий (на первом плане - логика) типы, а также типы, усваивающие информацию с помощью сенсорных органов чувств или с помощью интуиции. На основании перечисленных типов сформировались дихотомии Юнга (рациональность-иррациональность; этика-логика; сенсорика-интуиция). В четвертой дихотомии Юнга в основном подчеркивается степень подготовки человека к коммуникации, его социальности и общительности, что охватывает интроверсию и экстраверсию, сравнительный анализ которых проводится автором в рамках этой статьи.

Наряду с анализом влияния психологических типов на языковую личность, современные лингвистические исследования также изучают формы выражения различий, появившихся в результате этих типологических сравнений, на разных языковых уровнях (Закорко, 2009: 25-27; Хан, 2011: 147-151). Если быть точнее, то в результате исследований, относящихся к моделированию 
ассоциативной области, выявляемой в процессе усвоения интровертными и экстравертными людьми информации из окружающего мира, стало известно, что ассоциативный «круг» первых более глубокий и многослойный, тогда как ассоциативный «круг» эстравертов - широкий и более мелкий (Богословская, 2011: 28). Другими словами, если интроверты прибегают к помощи создающей функции их воображения для вызывания ассоциаций с каким-либо объектом, то экстраверты настраиваются на переход к другим ассоциациям. С этой точки зрения становятся совершенно ясными причины возникновения в некоторых случаях впечатления аффирмации от автобиографического рассказа Розамунд или же испытывание ею трудностей при переносе рефлексии с одного объекта на другой.

Анализ исследований. Статья посвящена исследованию языковой личности Марагарет Дрэббл и анализу интровертной личности, нашедшей выражение в еe романе «The Millstone». При исследовании статьи использовались такие научные статьи, относящиеся к этой теме: «Лингвосоционическое моделирование экстравертного и интровертного типов языковой личности» (Н. Д. Голев, А. В. Кузнецова), «Эмоциональнооценочный компонент значения слова (по материалам ассоциативного эксперимента с интровертами и экстравертами)» (С. В. Закорко), «Особенности компрессии репродуцированного текста в зависимости от психологических характеристик говорящего» (Н. А. Хан), «Моделирование ассоциативного поля экстравертов и интровертов: результаты психолингвистического эксперимента» (И. В. Богословская), «Картина мира: языковое видение интроверта» (М. В. Ляпон), «Система формальных средств коммуникации при создании текста» (А. Ю. Мамедов), «Возможность создания текста тематического членства» (А. А. Абдуллаев), «Ужин с «Ведьмой Экстраура» Маргарет Дрэббл» (Б. Пакиам), «В поисках утопии в прошлом, чтобы пережить настоящее: юнгианское прочтение царства золота» (Ш. Р. Систани, Ф. Багери), «Когнитивная лингвистика» (3. Д. Попова, И. А. Стернин), «Лингвистическая репрезентация концепта «любовь» в английском языке» (Е. А. Демина, Н. В. Кузнецова), «Психолингвистика и концептология» (И. А. Стернин), «Концепция ЛЮБВИ и ее концептуализация в современных английских любовных романах» (О.Х. Савчук, Н. М. Марченко).

Цель статьи - определить, является ли языковая личность самой М. Дрэббл, а также Розамунд Стадж, отражающей ее альтер-эго, экстравертом или интровертом в соответствии с дихотомией
Юнга и закрепить форму выражения этой особенности в художественном тексте. Сюжетом произведения является роман Маргарет Дрэббл «Жернов». Объектом исследования является исследование Маргарет Дрэббл языковой идентичности и, безусловно, идентичности интроверта.

Скорее всего, языковая идентичность этих романистов далека от природной контрзависимости, где речь не идет о солидарности с понятиями «Любовь» - «Страх» - «Одиночество» - «Опасение/Недоверие» - «Стыд». А это показывает, что каждый из этих макротекстов сам по себе является концептуальной сферой, где концепты зависят не только от национальной идентичности языка и языковой картины народа, но и от уникальности языка автора, «создателя» этой индивидуальной концепции, его языковой картины мира.

Этот анализ проводился с изучением источников, связанных с предметом, анализом полученных результатов, анализом и синтезом аргументов, а также методом сравнительного анализа.

Изложение основного материала. В статье «Вербальное мировоззрение интроверта: картина мира» М. В. Ляпон подчеркнул, что творческие личности, обладающие информационным метаболизмом такого типа, характеризуются избытком разъяснений, «хождениями вокруг денотата» и предоставлением особого места выражению внутреннего импульса, а непосредственное выражение автором-интровертом внутренних переживаний имеет особый вес (Ляпон, 2000: 199-201). Обратим внимание на «хождения вокруг денотата» главного героя М. Дрэббл, обладающего таким же интровертным характером, как и языковая личность автора: It was upon George that the whole delicate unnatural system was wrecked. Dear George, lovely George, kind and camp and unpretentious George (Дрэббл, 2010: 15). Внутреннее повествование почти peaлизовалось в форме аффирмации, в результате чего в автонарративных текстах данного типа неоднократно использовались антропонимы без какой-либо продуцивности (разрабатывание идеи) или описания, просто для выражения ситуативной экспрессии. Например: George, George, I thought of George... (Дрэббл, 2010: 44); Thinking of George, I even now permit myself some tenderness, now so much too late (Дрэббл, 2010: 15).

По сравнению с экстравертами, людям-интровертам сложно разделять свое внимание на несколько частей, поэтому переключение внимания с занятия, которым они увлечены, на другой вид деятельности или с мысли, над которой они глубоко задумались, на другую идею представляет для них определенную трудность. 
Мамедова Б. Г. гызы. Языковая мичность Маргарет АрэбБл ...

I became addicted and would spend hours over them; it was a soothing, time consuming process, and when I went to bed I would dream not of George, nor of babies locked away from me where I couldn't feed them, nor even of childbirth, but of pieces of blue sky edged with bits of tree, or small blue irregular shapes composing the cloak of the Virgin Mary. ... As a therapy, it worked extremely well; I found I could write my book and do a puzzle for alternate hours without getting unduly bored by either (Дрэббл, 2010: 66). Восприятие интровертом окружающего мира, объектов бывает общим, многоракурсным и несколько поверхностным. Первые (так же, как была связана Розамунд своими «зависимостями») страдают от того, что бывают слишком сильно увлечены чем-либо, а вторые переживают последствия того, что им трудно сосредоточиться на чем-то конкретном. Здесь М. В. Ляпон прослеживает следующие переходы: картина мира - языковая картина мира - текст, и отмечает, что интроверты выделяются специфичностью вербальных реакций на окружающие их раздражители. С этой точки зрения, произведение автора-интроверта отличается тем, что напрямую отражает «глубокие слои его (автора) психики, особенности ментального строения» (Ляпон, 2000: 199). Именно эти моменты наглядно прослеживаются в автонарративе главного героя.

"There's nothing to tell," I said, and thought of Octavia. Despite myself, I began to remember; I remembered how often I had reached for the phone, in those first months, to ring Broadcasting House and ask for George; how consciously I had restrained myself from going to the pub to see him, from walking the streets he might walk; how I had lain in bed at the hospital and listened through my institution earphones for his voice, how I had wept and lain awake and wished to share the misery of my child's affliction and the joy of her joy, how I had endured and survived and spared him so much sorrow, and I thought that now I did not see how I could go back on what I had done.

“It was nothing," I said. (Дрэббл, 2010: 122-123)

Данный отрывок представляет «обрамленное» собою сложное синтаксическое целое. ССЦ завершается повтором одной и той же мысли с разной интерпретацией: в начале - “There's nothing to tell, " Isaid; в конце - “It was nothing," I said.

Напомним, что, согласно А. Мамедову, среди формальных средств связи (1) фонетический повтор; 2) морфологический повтор; 3) лексический повтор; 4) синтаксический повтор; 5) лексически-грамматический повтор; 6) дейктические элементы), принимающих участие в образовании текста, лексические и синтаксические повторы выделяются своей интенсивностью (Мамедов, 2001: 25-27). По мнению А. Абдуллаева, считающего, что текст формируется в процессе раскрытия значения, вне зависимости от того, что повтор рассматривается здесь, как стилистическое средство, для усиления коммуникативной мощи текста (если быть более точным, с целью повышения интенсивности влияния на читателя в художественном тексте - Б. М.) он может употребляться как в смежных, так и в следующих друг за другом предложениях (Абдуллаев, 1996: 138). В отрывке, приведенном из произведения Дрэббл, мы наблюдаем текстообразование, выражающееся как синтаксическим, так и лексическим повтором. Как видно, в этом ССЦ для демонстрации внутренней экспрессии языковой личности интроверта, выражения бесконечного смятения, «заключенного в тишину», использовались ритмичные повторы. Синтаксический и лексический повторы, довольно характерные для стиля Дрэббл, служат не только интенции автора, но и во многих случаях применяются с целью гиперболизации эмоциональной нагрузки «внутреннего повествования», не выраженного открыто. Для языковой личности М. Дрэббл, «внешне» отличающейся своим спокойным тоном, не слишком характерно использование повторов с целью повышения декларативного тона. Если исключить повторные факты, перегруженные «экстраверсионной эмоциональностью», в антиамериканском эссе, написанном Дрэббл в 2003 году, то можно утверждать, что такого рода текстообразование используется ею в основном для имплицитного выражения внутренней экспрессии.

К. Г. Юнг также подчеркивал, что экстраверты выражают свои переживания более эмоционально, а интроверты своей тихой, спокойной реакцией как бы демонстрируют «особо преувеличенное равнодушие» (Юнг, 2002: 619-620).

Заметки об интровертном характере самой Маргарет Дрэббл, созданных ею образов (Пакиам; 19; Систани, 2014: 173-180) и, конкретно, главного героя романа "The Millstone" (Моррис, 1976: 97), позволяют нам узнать причины «поправки», сделанной в этом диалоге. Так, автор, в большинстве произведений исходящий именно из своего альтерэго, во всех своих произведениях отводит большую роль образам женщин с интровертным характером. Также мы можем сделать вывод, что в большей части ее творчества образы с интровертным характером являются главными героями ее произведений. Как мы отмечали ранее, сопоставление экстраверта и интроверта, берущее начало в дихотомиях К. Г. Юнга, основывается на при- 
роде отношений с окружающим миром, форме и спектре усвоения информации из этого мира (или, если использовать терминологию польского психиатра, психолога XX века А. Кемпинского, «информационный метаболизм»). Таким образом, если быть точнее, Юнг отмечает, что, в отличие от экстравертов, интроверты направляют свое внимание не на объект, а на субъект (то есть на самого человека - Б. М.), в связи с чем, он прослеживает стратегию их отдаления от объекта. «Он (интроверт - Б. М.) остается в стороне от внешних процессов, не вступает с ними в контакт и, даже попав в толпу людей, выказывает открытое негативное отношение к обществу и отказывается устанавливать с ним (обществом) близкие связи. $<\ldots>$ По мере увеличения числа людей возрастает интенсивность его противоположной реакции, возражения < . . > Его нельзя считать общительным человеком $<\ldots>$ Такой человек из-за своей замкнутости, чрезмерной сдержанности может показаться неприятным <..> и даже некультурным. По этой причине, сам того не желая, он может обидеть других людей» (Юнг, 2001: 282). Показанные в отрывке ситуации, связанные с коммуникативной тактикой Розамунд, а если точнее, с ее «бегством» от общения, подтверждают правоту Юнга.

When I saw her, I instantly turned and started to walk away but she must have looked up at the same moment, for I heard her call, in piercing Kensington tones, "Rosamund, Rosamund" (Дрэббл, 2010: 59); ...I tried to avoid her, deliberately, as I had not imparted the truth about Octavia, and did not wish to be trapped into doing so (Дрэббл, 2010: 90).

Известный британский психолог, автор теста IQ Г. Ю. Айзенкс выявил серьезные различия между экстравертами и интровертами во взаимодействии с обществом, отмечая, что если первые являются более социальными, общительными и импульсивными, то интроверты демонстрируют низкие показатели по всем этим аспектам (Зеленский, 2001: 13). Сложность Розамунд в умении общаться, наличие своего рода фобии доверительных отношений наглядно подтверждает следующий фрагмент из текста. Наблюдая внутреннюю рефлексию, типичную для интроверта, мы не можем проследить в сюжетной линии признание в любви: Words kept for ming inside my head, into phrases like I love you, George, don't leave me, George. I wondered what would happen if I let one of them out into the air. I wondered how much damage it would do (Дрэббл, 2010: 124).

Парадоксальность ситуации мы видим в том, что, будучи интровертом и демонстрируя соответствующую тактику в коммуникации, Розамунд
Джордан может родить ребенка, преодолев свою коммуникативную фобию, но не может строить с девочкой близких отношений и сказать правду о том, кто ее отец. Это дает возможность добавить еще одну деталь к психологическому портрету исследуемого. Таким образом, испытывание Розамунд трудностей в оказывании доверия кому-либо, проблемы коммуникации, а также страх быть запертой позволяют утверждать, что она страдает от контрзависимости. Напомним, что Розамунд Джордан скрывает ото всех тот факт, что не поддерживает близких отношений ни с одним молодым человеком (Nobody ever knew quite how odd my sexual life was and nobody, not even the men I deluded, would have been prepared to entertain the idea of my virginity (Дрэббл, 2010: 13)), а правду о том, что отцом ее дочери Октавии является Джордж, она скрывает не только от самой девочки, но и от семьи и близких друзей (I never told anybody that George was the father of my child. People would have been highly astonished had I told them, as he was so incidental to my life that nobody even knew that I knew him (Дрэббл, 2010: 11)), Розамунд обесценивает саму идею совместного будущего с Джорджем (It was no longer in me to feel for anyone what I felt for my child; compared with the perplexed fitful illuminations of George, Octavia shone there with a faint, constant and pearly brightness quite strong enough to eclipse any more garish future blaze (Дрэббл, 2010: 125)). Что же касается последнего пункта, то Юнг на передний план выдвинул тезисы «внимание интровертов направлено на внутренние психические комплексы» и «обособленность от окружающих реалий». После некоторых уточнений он также добавил, что в такие моменты интроверты используют не технологию «вытеснения», а руководствуются принципом «обесценивания" (Entwertung) (курсив наш - Б. М) (Юнг, 2001: 259). Кстати, отметим, что в своем автонарративе «Alterego Дрэббл», Розамунд признает, что сама страдает от внутренних психологических и противоречивых комплексов. Чтобы успешно выразить внутренние контрасты героя Дрэббл, необходимо использовать их вербальные репрезентованные антонимы, предварительно взяв языковые антиномии первого уровня (верхний семантический уровень): Sometimes I wonder whether it is not my parents who are to blame, totally to blame, for my inability to see anything in human terms of like and dislike, love and hate: but only in terms of justice, guilt and innocence (Дрэббл, 2010: 61). Через эти противостояния Дреббл пытается в корне исследовать слабость эмоционального интеллекта своего героя, анали- 
зируя психологические источники «парализованности» его эмоциональной экспрессии. Возвращаясь к обесцениванию, отметим, что возможное будущее, связанное с Джорджем, «бесцветное», а светлое будущее Октавии видится ей в «святом образе». «Несравненные» - при сравнении любимого ребенка и любимого человека - приоритет отдается первому, и это можно оценить, согласно утверждению Юнга, как вербальное «обесценивание». Возвращаясь к проблеме, связанной с контрзависимостью, отметим, что, как говорил Г. Хенригуес (Henriques), на первый взгляд, контрзависимость (Counter-Dependency) может создать впечатление здоровой автономии в отношениях. Однако это ложное представление. Таким образом, исследователи в этой области Janae and Barry Weinholdun отметили, что для контрзависимости характерны такие потребности, как перфекционизм, страх показать слабые стороны личности близким людям, быть всегда правым (a c учетом контрзависимого человека, значит, быть всегда справедливым и правильным - Б. М.) (Грегг, 2004). Эти признаки визуально отслеживаются в автонарративе Розамунд: I saw that from now on I, like that woman, was going to have to ask for help, and from strangers too: I who could not even ask for love or friendship (Дрэббл, 2010: 52); He said that if I wanted help of any sort I was to get in touch with him, but I wouldn't want help, would I, he said. No, I agreed (Дрэббл, 2010: 35), While he was stirring in his sugar, he said, "You don't feel like getting married, do you?" "Not particularly," I said. “In fact, not at all” (Дрэббл, 2010: 34). Понятие «помощь-благотворительность» не пересекается с понятием «дружба-взаимопомощь» в концептсфере Розамунд. Согласно Розамунд, эта концепция имеет прямую связь с понятиями «Слабость» и «Безуспешность».

Психологи утверждают, что контрзависимость вызвана страхом близости (fear of intimacy), и это психологическое состояние может характеризоваться мантрой «Мне никто не нужен» (“I don't need anyone"). Что касается исследователей, то они считают, что в мозгу людей, страдающих контрзависимостью, постоянно звучит «саундтрек напряженной самокритики» (soundtrack of intense self-criticism), несмотря на то, что они избегают общения и близости. Такие люди, даже если они в этом никому не признаются, страдают от одиночества, стыдятся, считая себя слабыми и бессильными тогда, когда им что-то нужно (Якобсон, 2015). А это, в свою очередь, еще раз выявляет состояние когнитивного диссонанса. Отрицание мечты, побег от реализации этого желания, желание и страх перед ним или связанный с ним стыд - все это приводит к ситуации когнитивного диссонанса, то есть к тому, что мысли, желания, интенции образуют контрастность с реальным поведением человека (Маклеод, 2018). Мы наблюдаем аналогичное поведение и интенционное противоречие в сценариях, которые находят отражение в концепции Розамунд и ее «любви». Усугубляет ситуацию то, что Розамунд является контрзависимой личностью с интровертным характером. Интроверсия нереализованными действиями и событиями, а также процессами, осуществляемыми «в мозгу», приобрела свою «завершенность». Розамунд в рамках приведенного текста, который мы будем ниже оценивать, «начинает и заканчивает» сюжет расследованием своих некоторых внутренних желаний, тем самым реализуя фрейм-сценарий: Occasionally, even now, I would picture to myself scenes in which he would arrive on my doorstep and greet me with phrases like "Rosamund, I've tried to live without you and I can't" or "Rosamund, I've loved you ever since I set eyes on you": occasionally, with shame, I would go through the whole romantic paraphernalia of meetings at the ends of long corridors, of embraces at the top of wide staircases, of passionate encounters at Oxford Circus. I would tell myself in reproof that these images were born of fear, not love, and so they doubtless were (Дрэббл, 2010: 52). Как видно, в языковой картине мира Розамунд для общего фрейм-сценария макроконцепции слова «Любовь» характерны серьезные связи с такими понятиями, как «Страх» и «Стыд». Известно, что «концептсфера - это область полного восприятия, которая состоит из понятий, находящих отражение в виде «изображений», схем, значений, фреймов, сценариев фрейма и гештальтов» (Попова, 2007: 43). С учетом исследований изучения английской национальной концептсферы мы можем определить, что эта связь не свойственна для идентичности английского языка. Так, лингвисты, изучающие понятия, присущие английской национальной идентичности, в частности, понятие «Любовь», отмечают, что в близкой периферии этой концепции расположены такие микроконцепции, как «Корыстная любовь», «Детская любовь (детство, подростковая любовь)», «Любовь с первого взгляда», «Безумная любовь», а в отдаленной периферии - «Семья» и «Ребенок (дети)» (Демина, 2011: 167-168). То есть в идентичности национального языка никоим образом не наблюдается концептуальная корреляция «Любви», «Страха» и «Стыда». Выдвигая на первый план «языковые средства, которые выступают в качестве средств материализации языко- 
вого сознания», Стернин отмечает, что к таким средствам относятся фразеологизмы, пословицы, а также отдельные слова и словосочетания. При этом на первый план выходит когнитивная интерпретация, так как «обычные» слова загружены значениями, определенными в соответствующей концепции (Стернин, 2007: 33-40). Различные концепции, реализуемые в рамках идентичности отдельных языков, могут быть оценены именно на базе когнитивной интерпретации, что делает возможным учет таких факторов, как гештальты, авторский психотип и т. д. Для сравнения скажем, что в произведениях таких романистов, как I. Gower, D. Macomber, S. Sheldon и D. Steel, исследователи, проследив за формами проявления понятия «Любовь», показали, что интенция и воображение автора, а также идентичность языка автора играют решающую роль в метафоризации внутри этой концепции (например: LOVE IS RAY OF SUNSHINE; OBSESSIVE FEELING OF LOVE IS FIRE / BLAZE; TENDER FEELING OF LOVE IS AIR / SUN; LOVE EXPERIENCES IS WIND / WHIRLPOOL и др.) (Савчук, 2018: 54-57).

Выводы. Скорее всего, языковая идентичность этих романистов далека от природной контрзависимости, где речь не идет о солидарности с понятиями «Любовь» - «Страх» - «Одиночество» - «Опасение/Недоверие» - «Стыд». А это показывает, что каждый из этих макротекстов сам по себе является концептуальной сферой, где концепты зависят не только от национальной идентичности языка и языковой картины народа, но и от уникальности языка автора, «создателя» этой индивидуальной концепции, его языковой картины мира.

\section{СПИСОК ИСПОЛЬЗОВАННЫХ ИСТОЧНИКОВ}

1. Абдуллаев А. А. Возможности создания текстов тематического членства : диссертация. Баку, 1996, 179 с.

2. Богословская И. В. Моделирование ассоциативного поля экстравертов и интровертов: результаты психолингвистического эксперимента: Вестник ЧелГУ. 2011. № 11 (226). C. 25-28. URL: https://cyberleninka.ru/article/n/ modelirovanie-assotsiativnogo-polya-ekstravertov-i-introvertov-rezultaty-psiholingvisticheskogo-eksperimenta.

3. Голев Н. Д., Кузнецова А. В. Лингвосоционическое моделирование экстравертного и интровертного типов языковой личности. Вестник КемГУ. Филология. 2009. № 3. C. 95-98. URL: https://cyberleninka.ru/article/n/ lingvosotsionicheskoe-modelirovanie-ekstravertnogo-i-introvertnogo-tipov-yazykovoy-lichnosti.

4. Грегг Э. Признаки контрзависимости. Психология сегодня. 2014. 11 апреля. URL: https://weinholds.org/ counterdependency.

5. Демина Е. А., Кузнецова Н. В. Лингвистическая репрезентация концепта «любовь» в английском языке. Вестник Нижегородского университета им. Н.И. Лобачевского. Серия : Филология. 2011. № 6 (2). С. 167-168.

6. Дрэббл М. The Millstone: Penguin Books. 2010, $176 \mathrm{c.}$

7. Закорко С. В. Эмоционально-оценочный компонент значения слова (по материалам ассоциативного эксперимента с интровертами и экстравертами). Вестник ЧелГУ. 2009. № 5 (143). С. 25-27. URL: https://cyberleninka.ru/ article/n/emotsionalno-otsenochnyy-komponent-znacheniya-slova-po-materialam-assotsiativnogo-eksperimentas-introvertami-i-ekstravertami.pdf.

8. Зеленский В. В. Карл Густав Юнг и аналитическая психология : Юнг К. Г. Психологические типьл. СанктПетербург : Азбука, 2001. С. 2-15. URL: http://transyoga.ru/assets/files/books/psychology/yung_tip_lichnosti.pdf.

9. Кокошка А. Информационный метаболизм как модель сознания : Международный журнал нейробиологии. 1993. № 68 (3-4). C. 165-177. URL: http://dx.doi.org/10.3109/00207459308994272.

10. Ляпон, М. В. Картина мира: языковое видение интроверта. Русский язык сегодня : сборник статей. Вып. 1. Москва : Азбуковник, 2000. С. 199-207.

11. Маклеод С. Когнитивный диссонанс : Simplyphychology, 2018. URL: https://www.simplypsychology.org/ cognitive-dissonance.html.

12. Мамедов А. Ю. Система формальных средств коммуникации при создании текста. Баку : Наука, 2001,144 с.

13. Моррис Р. К. Старые линии, Новые силы: Очерки современного британского романа, 1960-1970, Резерфорд, Мэдисон : Associated Univ Pr; Первое издание (1 июня 1976 г.), 211 c. URL: https://books.google.az/books?id=ksfF I2BkspEC\&pg=PA96\&lpg=PA96\&dq=drabble+margaret++introvert\&source=bl\&ots=3JqO9viXFz\&sig=ACfU3U0Zj3ux mnI_Jved31Teo3i3ln6GIw\&hl=ru\&sa=X\&ved=2ahUKEwj53vWPgaXkAhWPJ1AKHeVMC_oQ6AEwEXoECAkQAQ\# $\mathrm{v}=$ onepage $\& \mathrm{q}=$ drabble $\% 20$ margaret $\% 20 \% 20$ introvert $\& \mathrm{f}=$ false.

14. Пакиам Б. Обед с Маргарет Дрэббл «Ведьма из Экраура», 27 стр., Университет Линчёпинга. Департамент языка и литературы S-581 83 Линчёпинг, Швеция. URL: https://www.diva-portal.org/smash/get/diva2:606500/ FULLTEXT01.pdf.

15. Попова 3. Д.. Стернин И. А. Когнитивная лингвистика. Москва : АСТ: «Восток-Запад», $2007,314 \mathrm{s.}$

16. Савчук О. Х., Марченко Н. М. Концепция ЛЮБВИ и ее концептуализация в современных английских романтических романах : Наука и образование в новом измерении. Филология. 2018. VI (44), вып. 151. C. 54-57. URL: http://www.seanewdim.com/uploads/3/4/5/1/34511564/fil_vi_151_44.pdf\#page=54.

17. Систани Ш. Р., Багери Ф. В поисках утопии в прошлом, чтобы пережить настоящее: юнгианское прочтение царства золота. Достижения языка и литературы. 2014. Vol. 5. № 6. C. 173-180. URL: https://files.eric.ed.gov/fulltext/ EJ1128599.pdf.

18. Стернин И. А. Психолингвистика и концептология. Вопросы психолингвистики. 2007. № 5. С. 33-40. 
19. Хан Н. А. Особенности компрессии репродуцированного текста в зависимости от психологических характеристик говорящего. Вестник СПбГУ. Сер. 9. 2011. Вып. 1. С. 147-151. URL: https://cyberleninka.ru/article/n/ osobennosti-kompressii-reprodutsirovannogo-teksta-v-zavisimosti-ot-psihologicheskih-harakteristik-govoryaschego.

20. Юнг К. Г. Психологические типы. Санкт-Петербург : Азбука, 2001. 288 с. URL: http://transyoga.ru/assets/files/ books/psychology/yung_tip_lichnosti.pdf.

21. Юнг К. Г. Психологические типы. Психология мотивации и эмоций. Москва : ЧеРо, 2002. С. 609-622.

22. Якобсон Ш., Бланделл А. Опасности противоположной зависимости - когда вам никто не нужен. Наrley Therapy, 15 сентября 2015 г. URL: https://www.harleytherapy.co.uk/counselling/what-is-counterdependency.htm.

\section{REFERENCES}

1. Abdullaev A. A. Vozmozhnosti sozdaniya tekstov tematicheskogo chlenstva. [Opportunities for creating thematic membership texts] Dissertatsiya. Baku, 1996, 179 s. [in Russian].

2. Bogoslovskaya I. V. Modelirovanie assotsiativnogo polya ekstravertov i introvertov: rezultatyi psiholingvisticheskogo eksperimenta.[ Modeling the associative field of extroverts and introverts: results of a psycholinguistic experiment]. Vestnik ChelGU. 2011, N 11 (226). C. 25-28. URL: https://cyberleninka.ru/article/n/modelirovanie-assotsiativnogo-polya-ekstravertov-i-introvertov-rezultaty-psiholingvisticheskogo-eksperimenta (15.10.2020) [in Russian].

3. Golev N. D., Kuznetsova A. V. Lingvosotsionicheskoe modelirovanie ekstravertnogo i introvertnogo tipov yazyikovoy lichnosti [Лингвосоционическое моделирование экстравертного и интровертного типов языковой личности]. Vestnik KemGU, (Filologiya). 2009. N 3, s. 95-98. URL: https://cyberleninka.ru/article/n/lingvosotsionicheskoe-modelirovanieekstravertnogo-i-introvertnogo-tipov-yazykovoy-lichnosti (15.10.2020) [in Russian].

4. Gregg Enrikes Priznaki kontrzavisimosti [Signs of counterdependence]. Psihologiya segodnya, 11 aprelya 2014 g. [in Russian].

5. Demina E. A., Kuznetsova N. V. Lingvisticheskaya reprezentatsiya kontsepta "lyubov" v angliyskom yazyike [Linguistic representation of the concept "love" in English]. Vestnik Nizhegorodskogo universiteta im. N. I. Lobachevskogo, 2011. Seriya : Filologiya. N 6 (2). S. 167-168 [in Russian].

6. Drebbl M. The Millstone: Penguin Books. 2010, 176 p. [in English].

7. Zakorko S. V. Emotsionalno-otsenochnyiy komponent znacheniya slova (po materialam assotsiativnogo eksperimenta $\mathrm{s}$ introvertami i ekstravertami [The emotional-evaluative component of the meaning of the word (based on the materials of the associative experiment with introverts and extroverts]. Vestnik ChelGU, 2009. N 5 (143). P. 25-27. URL: https:/cyberleninka.ru/article/n/emotsionalno-otsenochnyy-komponent-znacheniya-slova-po-materialam-assotsiativnogo-eksperimenta-s-introvertami-i-ekstravertami.pdf (16.10.2020) [in Russian].

8. Zelenskiy V. V. Karl Gustav Yung i analiticheskaya psihologiya [Carl Gustav Jung and Analytical Psychology]. Yung K.G. Psihologicheskie tipyi. SPb : Azbuka, 2001. S. 2-15. URL: http://transyoga.ru/assets/files/books/psychology/ yung_tip_lichnosti.pdf (17.10.2020) [in Russian].

9. Kokoshka, A. Informatsionnyiy metabolizm kak model soznaniya [Information metabolism as a model of consciousness]. Mezhdunarodnyiy zhurnal neyrobiologii, 1993, 68 (3-4), 165-177 http://dx.doi.org/10.3109/00207459308994272 (18.10.2020) [in Russian].

10. Lyapon, M. V. Kartina mira: yazyikovoe videnie introverta[Picture of the world: linguistic vision of an introvert] : Russkiy yazyik segodnya: sb. statey. Vyip. 1, (otv. red. L. P. Kryisin), M.: Azbukovnik, 2000. S. 199-207 [in Russian].

11. Makleod S. Kognitivnyiy dissonans [The cognitive dissonance]. Simplyphychology, 2018. URL: https://www.simplypsychology.org/cognitive-dissonance.html (18.10.2020) [in English].

12. Mamedov A. Yu. Sistema formalnyih sredstv kommunikatsii pri sozdanii teksta [The system of formal means of communication when creating a text]. Baku, Nauka, 2001, 144 s. [in Azerbaijani]

13. Morris R. K. Staryie linii, Novyie silyi: Ocherki sovremennogo britanskogo romana [Old Lines, New Forces: Essays on the Contemporary British Novel], 1960-1970, Rezerford, Medison:Associated Univ Pr; Pervoe izdanie(1 iyunya 1976 g.), $211 \mathrm{s.}$ URL: https://books.google.az/books?id=ksfFI2BkspEC\&pg=PA96\&lpg=PA96\&dq=drabble+margaret++introvert\&source= bl\&ots=3JqO9viXFz\&sig=ACfU3U0Zj3uxmnI Jved31Teo3i3ln6GIw\&hl=ru\&sa=X\&ved=2ahUKEwj53vWPgaXkAh WPJ1AKHeVMC oQ6AEwEXoECAkQAQ\#v=onepage\&q=drabble\%20margaret $\% 20 \% 20$ introvert\&f=false $\quad(18.10 .2020)$ [in English].

14. Pakiam B. Obed s Margaret Drabbl «Vedma iz Ekraura»[ Dining with Margaret Drabble's The Witch of Exraoor], 27 str., Universitet LinchYopinga. Departament yazyika i literaturyi S-581 83 LinchYoping, Shvetsiya. URL: https://www.diva-portal.org/smash/get/diva2:606500/FULLTEXT01.pdf (18.10.2020) [in English].

15. Popova Z. D., Sternin I. A. Kognitivnaya lingvistika [Cognitive linguistics]. M.: AST: «Vostok-Zapad», 2007,314 s. [in Russian].

16. Savchuk O. H., Marchenko N. M. Kontseptsiya LYuBVI i ee kontseptualizatsiya v sovremennyih angliyskih romanticheskih romanah [The concept of LOVE and its conceptualization in modern English romantic novels]. Nauka i obrazovanie v novom izmerenii. Filologiya, VI (44), vyip . 151, 2018, p. 54-57. URL: http://www.seanewdim.com/uploads/3/4/5/ 1/34511564/fil_vi_151_44.pdf\#page=54 (18.10.2020) [in Russian].

17. Sistani Sh. R., Bageri F. V poiskah utopii v proshlom, chtobyi perezhit nastoyaschee: yungianskoe prochtenie tsarstva zolota[Seeking a Utopia in the Past to Endure the Present: A Jungian Reading of The Realms of Gold]. Dostizheniya yazyika i literaturyi, Vol. 5 N 6; Dekabr 2014 g., p. 173-180. URL: https://files.eric.ed.gov/fulltext/EJ1128599.pdf (18.10.2020) [in English]. 
18. Sternin I.. A. Psiholingvistika i kontseptologiya [Psycholinguistics and conceptology ]. Voprosyi psiholingvistiki. 2007. N 5. S. 33-40 [in Russian].

19. Han N. A. Osobennosti kompressii reprodutsirovannogo teksta v zavisimosti ot psihologicheskih harakteristik govoryaschego [Features of the compression of the reproduced text depending on the psychological characteristics of the speaker] : Vestnik SPbGU. Ser. 9. 2011. Vyip. 1, c. 147-151 [in Russian].

20. Yung K.G. Psihologicheskie tipyi [Psychological types]. SPb : Azbuka, 2001, 288 s. URL: http://transyoga.ru/assets/ files/books/psychology/yung_tip_lichnosti.pdf (18.10.2020) [in Russian].

21. Yung, K. G. Psihologicheskie tipyi [Psychological types]. Psihologiya motivatsii i emotsiy. M. : CheRo, 2002. S. 609-622. [in Russian].

22. Yakobson Sh., Blandell A. Opasnosti protivopolozhnoy zavisimosti - kogda vam nikto ne nuzhen [Dangers of the opposite addiction - when you don't need anyone]. Harley Therapy, 15 sentyabrya 2015. URL: https://www.harleytherapy. co.uk/counselling/what-is-counterdependency.htm (19.10.2020) [in Russian]. 